\title{
Islamic Epistemology as the Basis of Indonesian Nationalism
}

\author{
Happy Susanto ${ }^{1}$, Lia Amalia ${ }^{2}$ \\ Universitas Muhammadiyah Ponorogo, Indonesia ${ }^{1}$ \\ Institut Agama Islam Negeri (IAIN) Ponorogo, Indonesia ${ }^{2}$ \\ \{happybanget234@gmail.com $\left.{ }^{1}, \underline{\text { amaliamawahib@gmail.com }}{ }^{2}\right\}$
}

\begin{abstract}
The question of knowledge is the classic problem of man's age. The conversation begins with the question of how people gain knowledge. It creates various streams of knowledge that also talk about the validity of knowledge. The issue becomes the basis of conversation in epistemology. In the context of Indonesia, the discussion becomes interesting because the source of knowledge is not only derived from the reasoning and experience but also the noble values of the culture that includes religious teachings. Indonesia as a developing country is in the midst of changing times. Globalization forces Indonesia to open up to the changing times in which it also carries various ideologies. The values of knowledge that were formerly believed and taken for granted, nowadays a lot of re-questioning. The values of nationalism based on cultural and religious values are challenged by emerging new ideologies. Islamic epistemology which not only derives from rational-empirical knowledge but also revelation can be the basis of the bond of nationalism. A religion that contains the spirit of justice, togetherness, equality, and unity has proven to be the unifying of mankind beyond any value. In the context of development and development of human resources, religion can be a driving factor as well as a controlling factor to not fall into a dry civilization and only give priority to worldly values. Indonesia as an imagined community requires values that are not only based on experience and the mind but also the fundamental values of religion. This paper will examine the epistemology in general and the epistemology of Islam is imbued with the spirit of nationalism.
\end{abstract}

Keywords: Epistemology, Islamic Epistemology, Nationalism

\section{Introduction}

The discussion of epistemology is always related to knowledge. The term epistemology comes from the Greek, episteme which means subduing, placing or lying, whereas logos mean science. The word epistemology in Greek is often associated with the term derived gnosis which means to greet or deepen. Epistemology is further defined as knowledge or effort to put things in place while gnosisis interpreted as inner knowledge. But in its development, existing knowledge in the West and East especially Islam has a difference. The birth of enlightenment in the West greatly affects the formation of knowledge oriented to the sciences of the depth, while in the Islamic world; science is part of God's greatness. 
Epistemology is one of the philosophical schools that deals with knowledge. Epistemology in some places is associated with a discipline called Critica or Criteriology which means to judge, to decide and to place[1]. Epistemology can be interpreted as an intellectual effort in assessing and putting the right knowledge and where the knowledge is not right. The importance of this epistemological study in addition to studying the nature of knowledge is also related to the way man is himself. Man in the process of becoming in this world will continue to seek the right knowledge to sustain its existence. In the context of Indonesia, nationalism can be builton the basis of a common vision and mission based on knowledge derived from local cultural and religious values. This paper will discuss the epistemological view especially in the West which will then be compared with the Islamic world. This paper will also address how local knowledge (local wisdom) is positively correlated with nationalism.

\section{Literature review}

The problem of epistemology arises because of admiration[2]. Admiration in this context is equated with curiosity. No one can philosophize if there is no awe of something. This admiration prompted curiosity. This philosophical amazement arises not in the complicated but the obvious daily experience, for it is in the ordinary and the most difficult to describe[3]. There are five points in the study of epistemology. First, the analytical problem, the question of the nature of knowledge and how knowledge should be distinguished from belief or opinion. Second, the question of demarcation is to examine the limits of knowledge, such as what is meant by knowing and what is the limitation of human knowledge. Third, the problem of the method is to discuss how humans gain knowledge. Fourth, the problem of skepticism is the study of whether humans can acquire all the desired knowledge. This issue also leads to the question of knowledge justification, and fifth is the problem of value. This issue examines the use of knowledge for human life[4].

Epistemology is the science that asks questions like, "What is knowledge?" which then raises other questions like, "What does it mean to know?" and the opposite question "What does not know?", "What is an illusion?" , "What is consciousness?", What is conscious? "What is intuition? "And the various effects of other questions arising from the whole of human life[5].

Philosophy, which includes the epistemology, is a new development in a long human struggle to understand his life. Only a few concentrates on studying knowledge because most people believe in knowledge based on the majority opinion or beliefs that exist in society [6]. A common way of looking at knowledge based on lay ideals or the opinions of most people is called common sense. This layman's opinion has four main characteristics; first, it tends to be habitually and mimic the inheritance of the past. Second, common sense is vague and vague because it is still mixed between fact and prejudice. Thirdly, the opinion of ordinary people is mostly untested beliefs because people took for granted and fourthly, lay opinions rarely provide an adequate explanation of what is happening.

Epistemology is the branch of philosophy which investigates the origin, structure, methods, and validity of knowledge[7]. Rune also states that there are at least six subjects of the study of epistemology, namely, first, the nature of knowledge as to how humans really can know something, what the world we meet and think only a set of beliefs. Second, sources of knowledge that examine what problems sources of knowledge, whether human reason can acquire them; third, the validity of knowledge raises the question as to what is the validity of knowledge and what measure in the test of knowledge, the fourth, the limits of knowledge, 
which examine what is known and which can not be known by man, fifth, the kinds of knowledge that question whether the right size for the distinction, the classification and sharing of knowledge, and the sixth, the truth of the knowledge that concentrates on what is the nature of knowledge.

In a social context, epistemology concentrates on how to obtain an orderly knowledge, which is knowledge gained from normal circumstances, in which each creates and equips one another in where each level affects each other's actions. Each social layer contributes knowledge to create social reality[8].

Social epistemology is a social study of knowledge and information[9]. Social epistemology is very important to see the process of knowledge formation in society. Goldman divides epistemology into two branches of individual epistemology and social epistemology. These two branches of epistemology seek to identify and assess processes, methods or practices, whether positive or negative about how to obtain and produce true beliefs. Individual epistemology seeks to identify and evaluate the psychological processes occurring in the epistemic subject. While social epistemology seeks to identify and evaluate the social processes that occur in which the epistemic subject interacts with others and gives a mutual effect on their beliefs. Reciprocal communication and institutional institutions will direct and organizational communication and social practices.

\section{Method}

This research is library research where the data are taken based on the literature data. These data are studied in depth with various approaches. While the technique of data analysis using qualitative descriptive analysis.Qualitative data analysis consists of three procedures: First, data reduction. This refers to the process by which the mass of qualitative data can be obtained, is reduced and organized. Second, data display. To conclude from mass data, it takes a good view of data, in the form of tables, graphics, network,andgraphics formats. This is a continuous process, not just one to do at the end of data collection. Third,conclusion drawing/verification. The analysis should lead to the conclusion of the study. These initial conclusions can then be verified, i.e. the validity of those who are checked through references on existing field records or further data collection[10].

\section{Result and discussion}

\subsection{Knowledge in Islam}

Islam has its characteristics and uniqueness compared with knowledge in the West. In general knowledge in the West comes from the conclusion of experience (Empiricism) and reasoning (Rationalism)[11]. Empiricism is a theory that states that knowledge comes only or primarily from sensory experience. It emphasizes the role of experience and evidence, especially sensory perception, in the formation of ideas, and argues that the only knowledge humans can have is a posteriori. While Rationalism is any view appealing to intellectual and deductive reason (as opposed to sensory experience or any religious teachings) as the source of knowledge or justification. Rationalism also believes that knowledge comes from logic and a certain kind of intuition.

Meanwhile, the source of knowledge in Islam is not only come from Empiricism and Rationalism but also a revelation. According to M Azram in Islam, there are two types of 
knowledge: Revealed Knowledge and the knowledge gained in the life-search process (Derived Knowledge)[12]. These two sources of knowledge in Islam are all understood to originate from God, so it is not known by the term sacred knowledge and ordinary knowledge (profane) because in Islam everything is sacred.

The limitation of the physical and empirical realms of knowledge only leads to a secularistic world view. Modern cosmology offered by science in general does not introduce the spiritual elements that form the basis of traditional cosmology. Scientific cosmology introduces the Sun as the center of the solar system that is surrounded not only planet Earth but various other planets. Our next solar system is only a small part of the universe that contains millions of galaxies that continue to expand and away from each other. This universe is believed to occur without God's intervention and the law that comes from within itself and not from outside itself. While humans are understood as a complex biological system that has no special position because it is only a small part of this life. Man is understood not as God's great plan but as a process that comes naturally and accidentally. This is very different from the religious knowledge that sees man as God's image making him the representative on this earth.

Science sees everything that happens in nature with positivistic features that have reduced the substance and the essence of human beings which in the world of philosophy and religion have unique characteristics such as soul, heart, spirit and not merely a brain-based nervous system. This positivistic viewpoint threatens the position of human beings as free beings who have a moral and conscience in action which in the context of science is considered unreal even illusory. But at some point, it turns out that science is also shifting into the area of philosophy and religion. The limitation of knowledge only in the empirical or physical realm turns to form a materialistic world view that the real is material. Science is shifting from fact to speculation. By asserting that the real is the material things, science rejects metaphysical or spiritual realities[13].

Science and philosophy in certain contexts have differences. If science in its scientific base relies on sensory observation by examining facts whereas philosophy relies on reasoning by examining ideas. But different does not mean they have nothing to do at all. Many theories prevailing in the world of science take inspiration from philosophy as the modern science of positivism is affected. Likewise, many philosophical views are reflections of scientific theories as they occur in the logic of positivism and analytic philosophy. Philosophy is also a systematic knowledge that not only limits the physical knowledge but also the metaphysical. So in the world of Western epistemology that doubts the ontological status of ideas, philosophy is not called science while in Islamic epistemology that recognizes the ontological status of ideas, philosophy falls into the category of science. Philosophy in the process of research is more involving reasoning or rationality than the observation of the senses[14].

The philosophical worldview improves the limitations of science. In the view of human philosophers have a very noble position and not only consists of mechanical elements only. The mancan become a dignified creature by basing on moral actions and conscience that also has freedom of will. In addition to these elements, the most important thing that humans have is self-awareness and reason that can find the estuary of life on the spiritual life which is believed to guarantee not only life in the world but also life after the world.

Meanwhile, the basis of the religious view of the world is based not only on sensual observation and logical reasoning but also on revelation. The world is understood not as an independent reality but as a sign of God's greatness. All of God's creation that exists in this universe has a purpose to show His greatness, also as a lesson for man. So this universe in Iqbal terminology is called the "creative field" of God. Learning about nature will be the same 
as learning the way God created, the purpose of creation and God's "behavior or circumcision". Relating to humanity also places humans in a special place. Man is appointed Lord as his representative on Earth who has the authority to organize and preserve the Earth. A position never is given by any knowledge including the philosophy of humanism. But the authority and privilege of this man are also burdened by the rules of life or religious law for human life to achieve salvation [13].

Religion often speaks in symbolic and mystical language will greatly enrich and complement the two sources of limited knowledge. Religion finds its significance as the culmination of knowledge that not only ensures the salvation of life in the world but also in the afterlife. Knowledge in Islam will always find its sacred dimension for being able to find God. The word 'ilm and its various derivatives in the Qur'an are often used in the general sense that is knowledge which includes the meaning of the sciences of nature and humanities [15].

\subsection{Local Wisdom as a source of Nationalism}

Enlightenment knowledge encourages hedonist behavior because of the world-dominated view of materialism. Hedonism is a behavior that seeks to satisfy the urge and desire to gain pleasure because enjoyment is the goal of life. This hedonist behavior often sacrifices the noble values of the nation. The ideology of developmentalism, for example, eliminates many noble values, primarily related to the preservation of nature. Local wisdom is usually derived from the noble values of the nation itself as well as the religious values it embraces. In this context, the value and knowledge of religion can be a driving force and generator of a sense of nationalism. Religions that teach the values of justice will be a sprit to encourage equity development policies.

Modern humans experience a completely new condition. Religions previously able to provide order and meaning in the world (nomos) face a complex problem because they have to answer complex human problems. Modernization brings people to be complex and successive experiences. A religion that was formerly able to provide regularity that is like a sacred canopy for his followers in understanding the world threatened conditions of modernization. The complexity of human problems with varying degrees of experience, as if humans have no more conviction and more choice of judgments to decide. This condition is what Berger referred to the mind of the wandering or homeless of mind[16].

Religion according to Kuntowijoyo has the ideals of social justice,so Islam cando social criticism if the social changes that occur are not by the ideals of Islamic justice[17]. The Islamic movement must be based on the objective and empirical and not just normative interests that ignore the class differences and social stratification in society. Islam is a religion of human liberation and salvation whose orientation is based on transcendental ethics, meaning that religion is the sacred hood of human life. Religion is not a means of legitimizing the existing social system but must be able to control the behavior of the system itself. Islam must be the controller of the system, for that Muslims besides having to supervise the system must also have the ability and ability involved in it. Muslims must have a concept of methodology and axiology in the application of Islamic teachings.

Islam must build a theoretical paradigm by the epistemic and ethical framework by the teachings of Islam itself. Normatively Islam is a set of value systems that have absolute and transcendental truths. This Islamic normativity should be reduced to an operational framework through two media namely ideology and science. Islam becomes ideological because it not only constructs reality but also the ability to dismantle reality which is deemed incompatible with eschatological purposes based on its ethical values. The next process is Islam must be 
developed into a science by formulating and describing the normative concepts at the level of empirical and objective. Islamic normative values formulated into a theory that can be applied in everyday life. This is the evolution of the Islamic movement from the period of myth to the ideological period and ends in the period of science. The concept can be the basis of the Islamization of knowledge movement in the context of Indonesia.

The process of actualizing normative-subjective values to empirical reality-objectives for Kuntowijoyo must be done through five thinking reform programs[17]. First, it is necessary to develop a structural social interpretive program rather than an individualized form of interpretation as it understands certain provisions in the Qur'an. The interpretation of the prohibition of life spree should not only be seen in the context of the individual but must be seen the broader socio-economic context that is why the concentration of capital ownership occurs only in a handful of people. Second, change the subjective way of thinking to an objective way of thinking. This interpretation is done to present Islam to the objective ideals, such as the obligation to issue zakat in addition to the cleansing of property and soul, another objective goal is the achievement of social welfare. Third, converting normative Islam into theoretical. In general, the interpretation carried out is at the normative level and has not been developed into a framework of certain sciences. Normative interpretations of the poor are as the weak to be pitied through charity, infaq,and zakat. Through the theoretical approach can be seen why they become poor and poor and why they are in the social class. Fourth, change the a-historical understanding into historical. An understanding of the stories in the Qur'an tends to be a historic example of the oppression of the Israelites in the days of Pharaoh, only understood to have occurred at that time. Historically the repression occurred in every age and different context. The system of capitalism, for example, has conducted oppression against small traders and ordinary people. Fifth, formulate generalized revelatory formulations into specific and empirical formulations. The Quran denounces the occurrence of the circulation of wealth only on certain groups, so in the present context, it should be understood that God also condemns the monopolistic practice in the field of economy and politics made only by a handful of people. With these five reform agendas, the Islamic normative ideal will be realized in rational, objective and empirical actions.

The spirit of values of justice in Islam can be the basis of building nationalism where every human being is bound by the noble values of religion even though they may never meet each other. The nation is an imagined community because they may not know each other, meets and hear, but are united by certain agreed ties, so that although this community is colored by differences and gaps, they remain united in a strong fraternity. It is in this context that the noble values of Indonesia originating from local and religious values are the means to unite the Indonesian nation because they are highly relevant to the spirit of nationalism[18].

\section{Conclusion}

The discourse of knowledge associated with nationalism is always interesting to discuss. Man himself on the development of his life always find new sciences to overcome the problems achieved. The invention can overcome problems but can also create problems because their discoveries lead to the destruction of social order and the natural order. Religious knowledge and noble local knowledge can be a controlling factor for the development of science into the value of human excellence. In the context of Indonesian, the noble values of the Indonesian nation are derived from local values in a long dialectical process. The value of religion became a very strong spirit of nationalism from the struggle for independence until the time of this development. In the context of the present moment, the 
urgent need is to restore the noble spirit of these values so that this nation does not lose the soluble direction alongside other ideologies

\section{References}

[1] W. Aholiab, Tanggung Jawab Pengetahuan: Mempertimbangkan epistemologi secara Kultural. Yogjakarta, Kanisius, 2001.

[2] K. T. Gallagher, Epistemologi: Filsafat Pengetahuan. Yogjakarta: Kanisius, 1994.

[3] A. Ikhwan, Filsafat Pendidikan Islam: Memahami Prinsip Dasar. Yogyakarta: Diandra Kreatif, 2018.

[4] M. William, Problems of Knowledge, a Critical Introduction to Epistemology. London: Oxford University Press, 2001.

[5] A. J. Bahm, Epistemology: Theory of Knowledge, World Books. Albuquerque: Las Lomas Rd.N.E, 1995.

[6] Titus Harold.H., M. S. Smith, and R. T. Nolan, Living Issues in Philosophy. New York: Van Nostrand Company, 1994.

[7] D. Guralnik, Ed., Webster's New World Dictionary of the American Language. Boston: Houghton Mifflin Harcourt, 1962.

[8] S. Fuller, Social Epistemology. Blomington: Indiana University Press, 1988.

[9] A. Goldman, Knowledge in Social Work. Oxford University Press, Oxford, 1999.

[10] Kuntowijoyo, Dinamika Sejarah Umat Islam Indonesia. Yogyakarta: Shalahuddin Press dan Pustaka Pelajar, 1994.

[11] A. Ikhwan, "TEORI DASAR METODE STUDI ISLAM (Pembacaan atas Pemikiran Charles J. Adams dan Richard C. Martin)," At-Tasyrih J. Pendidik. Islam, vol. 1, no. 1, 2015.

[12] M. Azram, "Epistemology -An Islamic Perspective," IIUM Eng. J., vol. 12, no. 5, pp. 179-187, 2011.

[13] M. Kartanegara, "Ketika Sains Bertemu Filsafat dan Agama," J. Relig., vol. 1, no. 1, 2003.

[14] H. Susanto, Epistemologi Ilmu-Ilmu Sosial: Kajian Kritis tentang Asumsi Dasar, Paradigma, dan Kerangka Teori dalam Ilmu Sosial,. Yogyakarta: Ump Press dan Kurnia Kalam Semesta, 2015.

[15] M. Golshani, "Science and Sacred," in International Conference on Religion and Science in the Post-Colonial World, 2003.

[16] P. L. Berger, Berger, B., and H. Kellner, The Homless Mind. New York: Randon House, 1973.

[17] Kuntowijoyo, Budaya dan Masyarakat. Yogyakarta: Tiara Wacana, 1987.

[18] B. Anderson, Imagined Communites: Komunitas-Komunitas terbayangkan. Yogyakarta: Insist dan Pustaka Pelajar, 2008. 